\title{
Chemical composition and carbohydrate content of seeds from several lupin species
}

\author{
Jolanta Gdala and Lucyna Buraczewska \\ The Kielanowski Institute of Animal Physiology and Nutrition, \\ Polish Academy of Sciences \\ 05-110 Jablonna, Poland
}

(Received I July 1996; accepted I3 September 1996)

\begin{abstract}
The chemical composition of mature whole seeds of six cultivars of yellow lupin (Lupinus luteus L.), three cultivars of white lupin (Lupinus albus L.) and two cultivars of narrow-leaved lupin (Lupinus angustifolius L.) was determined with particular attention to the content of $\alpha$-galactosides and non-starch polysaccharides.

$\alpha$-Galactoside contents significantly differed among lupins, averaging (per kg DM) 105,85 and 60 $\mathrm{g}$ in yeilow, white and narrow-leaved lupins, respectively. Stachyose was the dominant $\alpha$-galactoside; its level in seeds of yellow and white lupins was similar (about $60 \mathrm{~g}$ ) and significantly higher than in seeds of narrow-leaved lupins (about $33 \mathrm{~g}$ ). Opposite proportions of the minor $x$-galactosides, galactopinitol, digalactopinitol and digalactoinositol, were observed. The highest proportion of verbascose was found in the seeds of yellow lupins.

Yellow lupins seeds contained significantly less non-starch polysaccharides $(321 \mathrm{~g})$ than other lupins (about $400 \mathrm{~g}$ ). Glucose and galactose constituted the main part of NSP sugar residues (from 31 to $43 \%$ and from 31 to $32 \%$, respectively). Considerable differences among species were found in the contents of rhamnose, xylose, galactose and uronic acids.
\end{abstract}

KEY WORDS: lupins, $x$-galactosides, non-starch polysaccharides

\section{INTRODUCTION}

Lupin seeds vary significantly in their nutrient contents. L. luteus seeds have the highest protein content, while those of $L$. albus are recognized as having a high level of oil (Hill, 1977). Also, differences in the content and chemical composition of $\alpha$-galactosides and non-starch polysaccharides (NSP) can be

The research was financed by grant No 00336/S3 05 from the Committee for Scientific Research 
observed among lupins. $x$-Galactosides, the main cause of flatulence in human beings and animals, occur in amounts ranging from 70 to $120 \mathrm{~g} / \mathrm{kg}$ dry matter of seeds (Trugo et al., 1988). Reported NSP levels vary among lupins from $270 \mathrm{~g}$ in L. luteus to $370 \mathrm{~g}$ in L. angustifolius (Gdala et al., 1994). Although $\alpha$-galactosides and non-starch polysaccharides represent a significant proportion of whole lupin seeds, they are not hydrolyzed by the digestive enzymes of pigs. However, they can be broken down by intestinal microflora, especially in the large intestine. The end products of bacterial fermentation are, among others, volatile fatty acids - an important source of energy for pigs.

The aim of the present study was to characterize the chemical composition of seeds of different lupins with special regard to carbohydrates. A comparison was drawn both among cultivars within each lupin species as well as among lupin species. Variation in nutrient content was evaluated in cultivars of L. luteus, $L$. albus and $L$. angustifolius over three consecutive growing seasons.

\section{MATERIAL AND METHODS}

Seeds

Seeds of six cultivars (Amulet, Cybis, Juno, Manru, Popiel, Radames) of yellow lupin (Lupinus luteus L.), three cultivars (Bardo, Hetman, Wat) of white lupin (Lupinus albus L.) and two cultivars (Saturn and Sur) of narrow-leaved lupin (Lupinus angustifolius L.) were used in the study. Seed samples were supplied by three Plant Breeding Stations located in west, north-west and central regions of Poland. The seeds of each lupin cultivar were collected and analyzed for three consecutive years.

\section{Analytical procedures}

Dry matter (DM), nitrogen (N), fat, ash and crude fibre (CF) were analyzed using standard methods (AOAC, 1990). The contents of neutral detergent fibre (NDF), acid detergent fibre (ADF) and acid detergent lignin (ADL) were determined according to the Van Soest and Wine (1967) and Van Soest (1973) methods. Hemicellulose and cellulose were calculated as differences (NDF - ADF and ADF - ADL, respectively). Sucrose and $\alpha$-galactosides were exiracted from milled lupin seeds for $30 \mathrm{~min}$ at $100^{\circ} \mathrm{C}$ in 10 parts of $50 \%$ ethanol under reflux. The suspension was then poured into a test tube and centrifuged. Carbohydrate derivation was performed according to the method described by Horbowicz and Obendorf (1994). The carbohydrate derivatives (TMS) were 
analyzed using a Pye Unicam Model 204 gas chromatograph equipped with a flame ionization detector and a packed column $(90 \mathrm{~cm} \mathrm{x} 4 \mathrm{~mm}, 3 \%$ OV17 on $80 / 100$ Chromosorb W) operated with a programmed initial temperature of $200^{\circ} \mathrm{C}$ for $2 \mathrm{~min}$, adjusted to $340^{\circ} \mathrm{C}$ at $12^{\circ} \mathrm{C} / \mathrm{min}$, and held at $340^{\circ} \mathrm{C}$ for $15 \mathrm{~min}$. The injector part was operated at $280^{\circ} \mathrm{C}$ and the detector at $350^{\circ} \mathrm{C}$. The carrier gas was argon flowing at $20 \mathrm{ml} / \mathrm{min}$, hydrogen $(30 \mathrm{ml} / \mathrm{min})$ and air $(400 \mathrm{ml} / \mathrm{min})$. Total NSP and their constituent sugars were determined as alditol acetates by gas-liquid chromatography (GLC) for neutral sugars and by colorimetry for uronic acids using the methods of Englyst and Cummings (1984).

\section{Statistical analysis}

The average and standard deviations were calculated for each analyzed sample taken from three consecutive years. A simple analysis of variance (ANOVA) was performed to evaluate the statistical significance of differences either among cultivars within each lupin species or among lupin species. Correlation coefficients were also calculated (Statgraphics Plus vr 7.0, 1993).

\section{RESULTS AND DISCUSSION}

\section{Lupinus luteus cultivars}

The weight of one thousand seeds (122-135 g) did not differ significantly among cultivars (Table 1). However, seeds of lupins Manru, Amulet and Cybis showed greater weight variation than the seeds of other cultivars. The crude protein $(\mathrm{N} \times 6.25)$ content ranged from 422 to $444 \mathrm{~g} / \mathrm{kg}$ DM. Standard deviation calculated for this component of Manru and Radames seeds was large in relation to differences among years. The basic chemical composition of the tested seeds was similar to that previously reported by Hove (1974), Withers et al. (1975), Hill (1977) and Múzquiz et al. (1989).

The fraction of insoluble structural carbohydrate (NDF) in whole seeds consisted mainly of cellulose and, to a lesser extent, of hemicelluloses. However, some hemicelluloses can be lost during NDF assay because most hemicelluloses originate from the cell walls of cotyledons $(70 \%)$, and one-third of those from hulls are water-soluble (Cerning-Béroard and Filiatre-Verel, 1980). A negative correlation $(\mathrm{r}=-0.54, \mathrm{P}=0.02)$ was found between the content of $\mathrm{ADF}$ and crude protein and, as expected, a positive correlation $(\mathrm{r}=0.89, \mathrm{P}=0.001)$ was observed between cellulose and the CF fraction.

The total NSP content ranged from 272 to $353 \mathrm{~g} / \mathrm{kg}$ DM of whole lupin seeds. Non-starch polysaccharides were mainly composed of glucose (in $43 \%$ ) and 


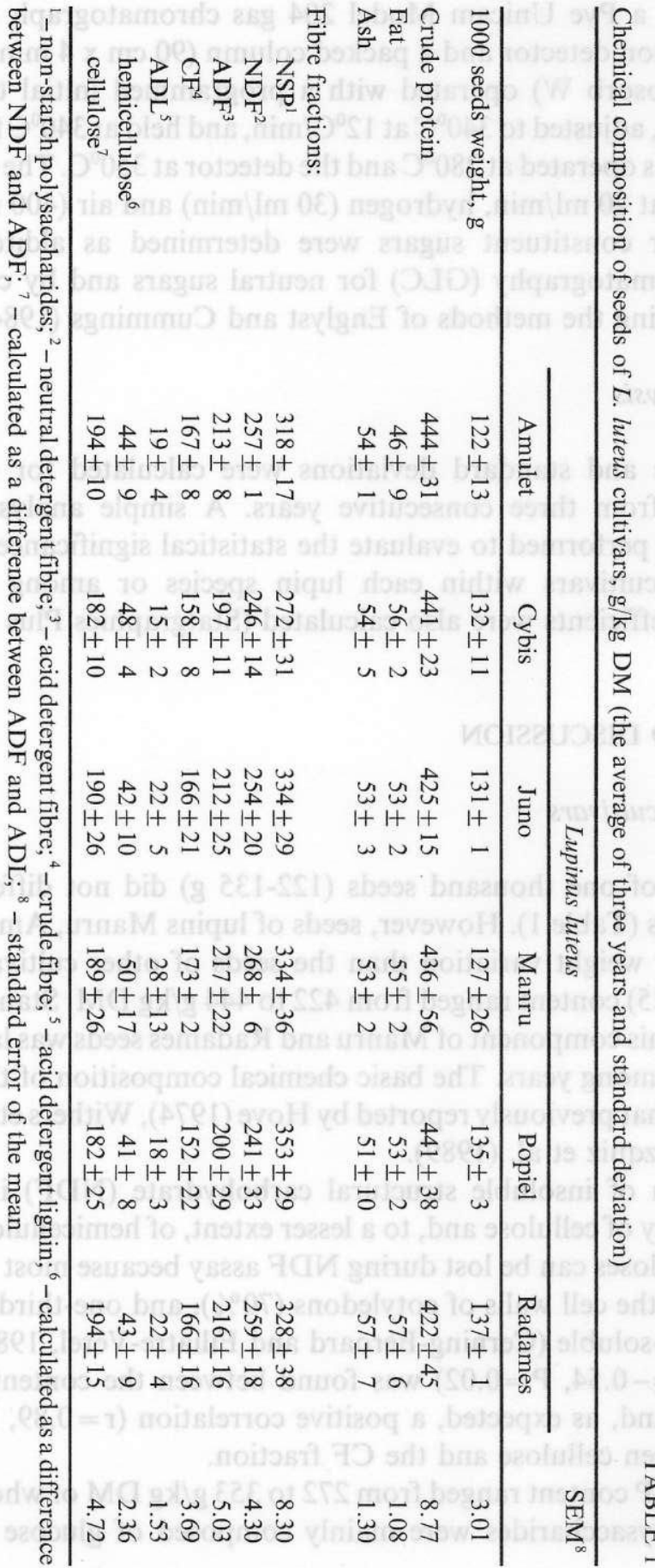


galactose (in 19\%). The average proportions of other NSP constituents, arabinose $(12 \%)$, xylose $(11 \%)$ and uronic acids $(11 \%)$ were in an intermediate range, whereas mannose $(2 \%)$, rhamnose $(<1 \%)$ and fucose $(<0.5 \%)$ were minor sugar residues. In the studies of Cerning-Béroard and Filiatre-Verel (1980) xylose, arabinose, galactose and very small amounts of rhamnose and glucose were detected when cell wall polysaccharides of lupin seeds were hydrolyzed in mild acid. Stronger acid $\left(72 \% \mathrm{H}_{2} \mathrm{SO}_{4}\right)$ liberated mainly glucose as the degradation product of cellulose, but small quantities of pentoses were also present. The study by Brillouet and Riochet (1983) showed that cell walls from cotyledons of $L$. luteus seeds contained galactose, arabinose and uronic acids as major sugar constituents; cell wall material from hulls was composed mainly of glucose, xylose and arabinose. A positive correlation $(\mathrm{r}=0.71, \mathrm{P}=0.001)$ was observed between the level of total NSP and that of galactose.

The oligosaccharide fraction in mature dry seeds ranged from 10.0 to 17.4 $\mathrm{g} / \mathrm{kg}$ DM (Table 2). Galactopinitol, galactoinositol, digalactopinitol and digalactoinositol were minor $\alpha$-galactosides in seeds, which is in agreement with results of Sosulski et al. (1982) and Horbowicz and Obendorf (1994). A negative correlation was found between sucrose and galactoinositol $(\mathrm{r}=-0.74, \mathrm{P}=0.001)$ and also between sucrose and digalactoinositol $(r=-0.54, P=0.02)$. The level of raffinose was low $(9.6-12.3 \mathrm{~g} / \mathrm{kg}$ ) and similar for all tested cultivars. Verbascose, whose level significantly varied among cultivars, represented on average $26 \%$ of the total $\alpha$-galactosides. Stachyose was the main sugar component $(57 \%$ on average) of the raffinose family oligosugars. Contrary to this finding, Múzguiz et al. (1989) reported a very low level of stachyose $(9.6 \mathrm{~g} / \mathrm{kg})$, while Cerning-Béroard and Filiatre (1976) found verbascose to be the dominant $\alpha$-galactoside in yellow lupin seeds. The total content of $\alpha$-galactosides in seeds varicd from 90.2 to 116.1 $\mathrm{g} / \mathrm{kg}$ and was similar to that reported by other authors (Cerning-Béroard and Filiatre-Verel, 1980; Trugo et al., 1988). It seems that both genetic and environmental effects contributed to the observed differences in the content and composition of $\alpha$-galactosides (Trugo et al., 1988). It is also possible that some differences in total oligosaccharides, as well as in the levels of individual compounds, within the lupin species, resulted from the procedure employed for the extraction of $\alpha$-galactosides from seeds (Saini, 1988).

\section{Lupinus albus cultivars}

One thousand seeds weighed from 255 to $331 \mathrm{~g}$ (Table 3). These data arc in accordance with the results of Brillouet and Riochet (1983), who reported values from 260 to $466 \mathrm{~g}$. The crude protein content in seeds varied from 307 to $374 \mathrm{~g}$, but the differences among cultivars were not statistically significant. The level of oil in seeds did not differ very much $(102-108 \mathrm{~g} / \mathrm{kg})$. The oil is mainly composed of 

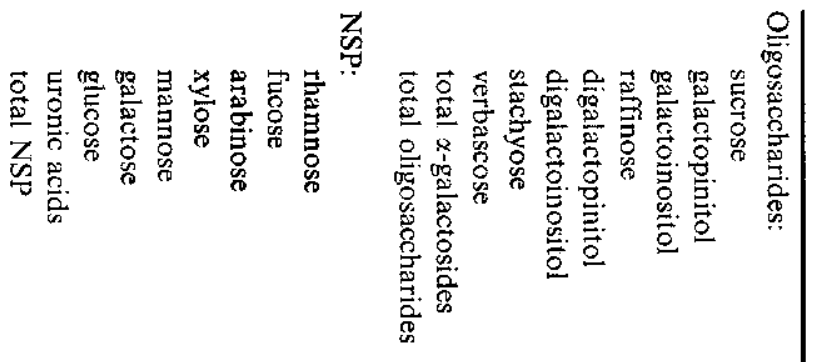

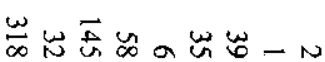

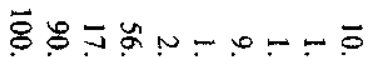
H H H H H H H H

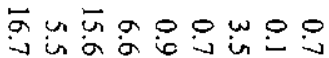

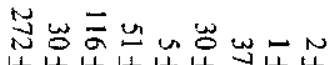

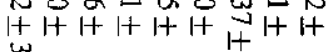

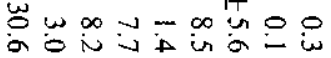

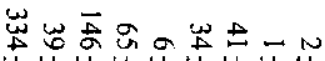
HH H H $+1+1+1+$

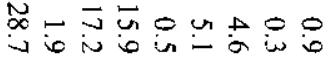

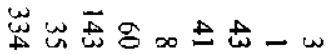
H H H H H H H

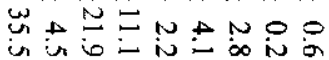

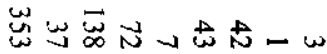
HHHHHHH H H

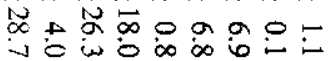

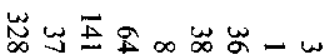
H H H H H H H H

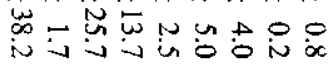

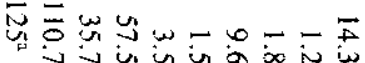

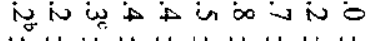
H $1+H+H+1+H+H$ w

귱ㅇㅇㅇㅇㅠ

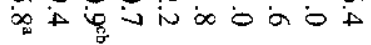
H H H H H H H H H un un 0000004 in $\rightarrow$ is 0 \& $A$ o 00 $\mathrm{H} H \mathrm{H}+\mathrm{H}+\mathrm{H} H \mathrm{H}+\mathrm{H}$

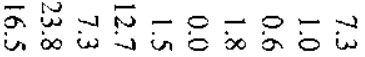

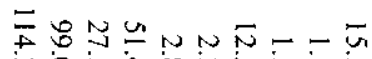

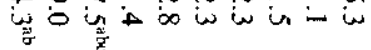
H H H H H H H it H H

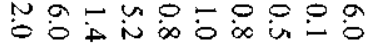

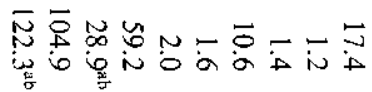
$\mathrm{H} H \mathrm{H}+\mathrm{H}+\mathrm{H}+\mathrm{H}+\mathrm{H}$ $\vec{\infty}-\vec{\omega} 00 \omega 00 \infty$

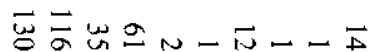

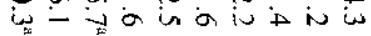
H $+1+H+1+H+1+H$

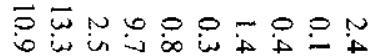

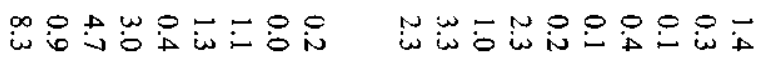

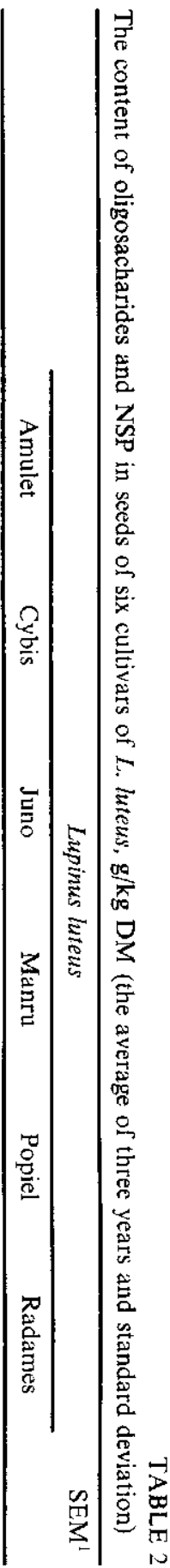




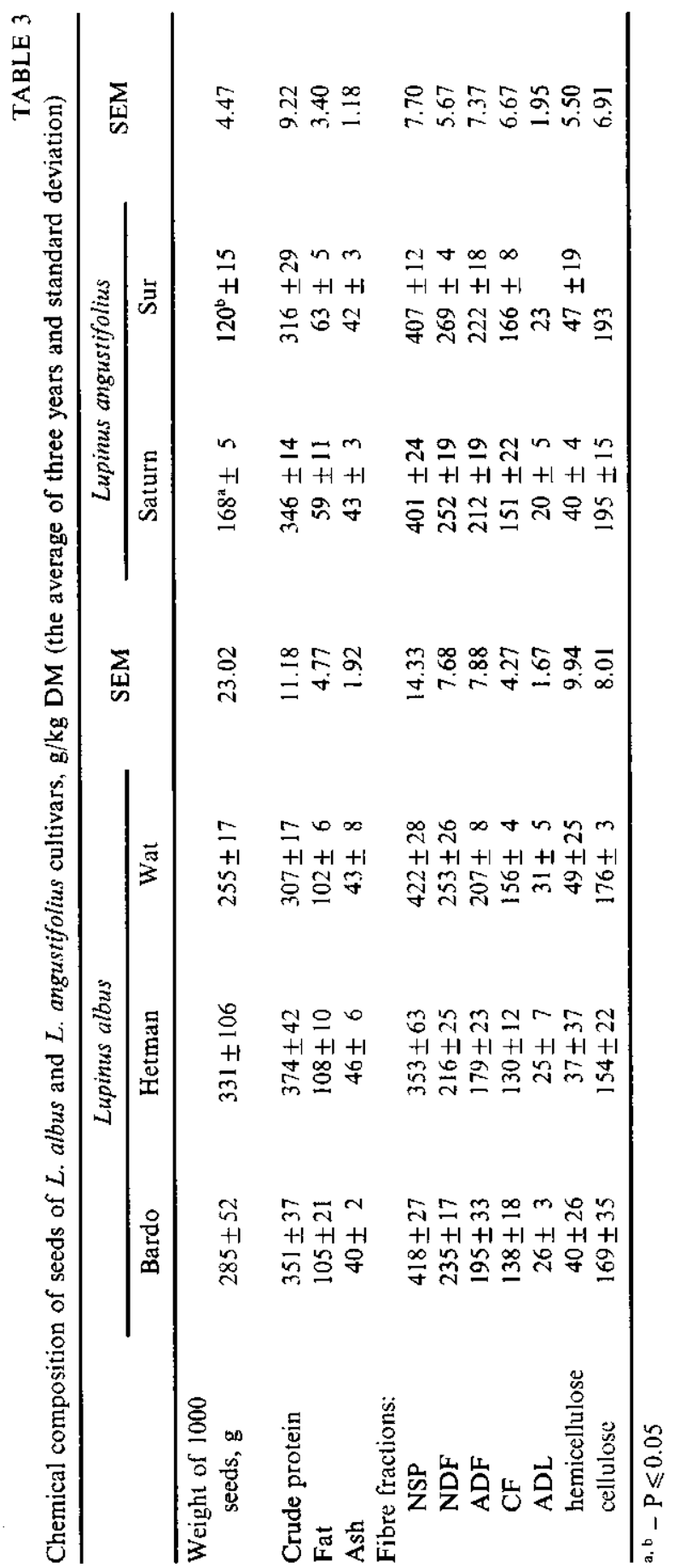


unsaturated long chain fatty acids, mainly oleic, linoleic and $\alpha$-linolenic acid, which on average account for 50,22 and $10 \%$ of total fatty acids, respectively (Green and Orad, 1983).

The amount of hemicellulose and cellulose ranged from 37 to $49 \mathrm{~g}$ and from 154 to $176 \mathrm{~g}$, respectively. A positive correlation $(\mathrm{r}=0.74, \mathrm{P}=0.02)$ was observed between cellulose and $C F$, but a negative one $(r=-0.70, P=0.04)$ between cellulose and the oil level. The weight of lupin seeds negatively $(r=-0.81$, $P=0.01$ ) influenced the CF content.

The content of NSP components and oligosaccharides in seeds of white lupins is presented in Table 4. Similarly to NSP of yellow lupin seeds, rhamnose, fucose and mannose were found in small quantities. Arabinose, xylose and uronic acids had intermediate values, while glucose and galactose were major sugar residues (31 and $32 \%$ of total NSP, respectively). This is in agreement with the results of Daveby and Åman (1993), who reported that galactose, arabinose and uronic acids were the main components of non-starch polysaccharides in dehulled lupin seeds. The NSP composition of white lupin cotyledons indicates a low content of cellulose $(50 \mathrm{~g} / \mathrm{kg})$ and a high content of pectic substances $(710 \mathrm{~g} / \mathrm{kg})$, which were mainly composed of (1 4 ) galactan with small numbers of branched points on galactose units (Carré et al., 1985).

Seeds contained 18.2-32.6 g/ $\mathrm{kg}$ DM sucrose and much less galactopinitol, galactoinositol, digalactopinitol and digalactoinositol. The amount of stachyose in white lupins was high (48.5-75.3 g), while that of raffinose $(8.8-10 \mathrm{~g})$ and verbascose (2.2-7.1 g) was low. Similar proportions of $\alpha$-galactosides in seeds of Lupinus albus cultivars were reported by Cerning-Béroard and Filiatre-Verel (1980) and Macrae and Zand-Moghaddam (1978). The correlation coefficient between raffinose and sucrose was $\mathrm{r}=0.80, \mathrm{P}=0.01$. Total $\alpha$-galactoside contents in lupin seeds varied from 68.0 (Hetman) to $100.1 \mathrm{~g} / \mathrm{kg} \mathrm{DM}$ (Wat) and correlated with stachyose and verbascose contents $(\mathrm{r}=0.98, \mathrm{P}=0.001$ and $\mathrm{r}=0.87, \mathrm{P}=0.002$, respectively).

\section{Lupinus angustifolius cultivars}

Saturn seeds were significantly bigger than Sur seeds and weighed 168 vs. $120 \mathrm{~g} / 1000$ seeds (Table 3 ). There were no significant differences between lupins in the contents of crude protein, fat, ash and NSP in seeds. The levels of NDF, ADF and CF, but not of ADL, were slightly higher in Sur seeds than in Saturn seeds. Hemicellulose and cellulose contents were comparable in the seeds of both cultivars. High positive correlations were found between ADF and ash $(r=0.89$, $\mathbf{P}=0.04), \mathrm{CF}(\mathrm{r}=0.98, \mathbf{P}=0.004)$, and cellulose $(\mathrm{r}=0.98, \mathbf{P}=0.002)$. The approximate composition of whole seeds of narrow-leaved lupins was comparable with that given by Hill (1977) and Múzquiz et al. (1989). 
The NSP chemical composition of whole seeds of L. angustifolius cultivars was similar to that found for whole seeds of other lupin species (Table 4). Generally, rhamnose, fucose and mannose were minor NSP constituents. Arabinose, xylose and uronic acids had intermediate values, while galactose and glucose were the dominant sugar residues. A negative correlation was found between the level of uronic acids and that of arabinose $(\mathrm{r}=-0.90, \mathrm{P}=0.01)$, and fucose $(\mathrm{r}=-0.85, \mathrm{P}=0.03)$.

The sucrose content was significantly higher in Saturn seeds $(19.2 \mathrm{vs.} 14.0 \mathrm{~g} / \mathrm{kg}$ DM) than in Sur. Galactopinitol, galactoinositol, digalactopinitol and digalactoinositol were found in small amounts. Stachyose dominated among the raffinose family oligosaccharides ( $29.9 \mathrm{~g}$ in Saturn and $35.3 \mathrm{~g}$ in Sur), while raffinose and verbascose were found at the same low level ( 7 and $10 \mathrm{~g}$ ). In studies by Saini (1988), verbascose represented nearly $17 \%$ of the total $\alpha$-galactosides in seeds of narrow-leaved lupin. In the present study the respective value was slightly lower, $14 \%$. In contrast, according to Cerning-Béroard and FiliatreVerel (1980), verbascose was the predominating oligosugar $(35-43 \%$ of total ethanol-soluble sugars) in the seeds of $L$. angustifolius.

\section{Interspecies differences}

Of the three lupin species, L. albus seeds were bigger $(\mathrm{P}<0.05)$ than those of L. luteus and L. angustifolius (Table 5). Significant differences among species were found in the content of crude protein, fat, ash and non-starch polysaccharides. More protein and ash, but less NSP was determined in seeds of $L$. luteus than in those of $L$. albus and $L$. angustifolius. The highest level of fat $(\mathrm{P}<0.05)$ was found in seeds of $L$. albus. No significant differences were observed in the content of fibre fractions, but there were some differences in the content of sucrose, $\alpha$-galactosides and NSP components. The sucrose level was the highest in the seeds of L. albus, while that of galactopinitol was highest in the seeds of $L$. angustifolius. The latter also contained the highest level of digalactoinositol and digalactopinitol. The level of the dominant oligosaccharide in all of the species, stachyose, in the seeds of $L$. luteus and $L$. albus was double that in L. angustifolius. L. luteus seeds had the highest verbascose content. Generally, the level of total $\alpha$-galactosides significantly differed in the lupins. Seeds of $L$. angustifolius contained more NSP $(\mathrm{P}<0.05)$ than seeds of $L$. luteus and $L$. albus. Some considerable differences among lupins were found in the content of rhamnose, xylose and uronic acids, but the most characteristic difference pertained to the galactose level. The cell wall material of $L$. angustifolius and L. albus seeds contained a twofold higher level of galactose than that of L. luteus. The main NSP of the lupin seeds is a highly complex branched structure containing $\alpha$-arabian and $\beta$-galactan side chains attached to a pectin-like main 


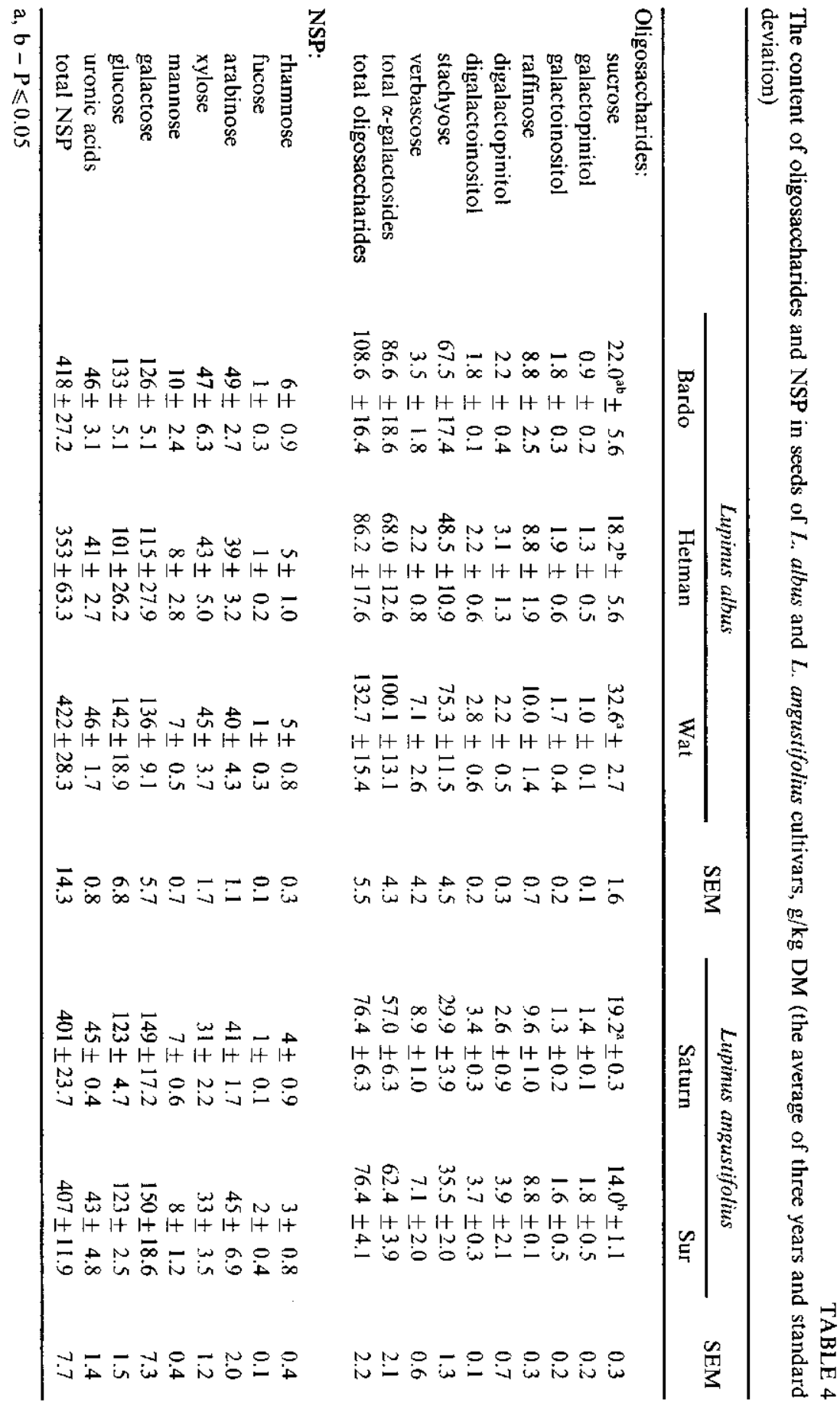


TABLE 5

Comparison of chemical composition of seeds of three lupin species, g/kg DM

\begin{tabular}{|c|c|c|c|c|}
\hline Species & L.luteus & L. albus & L.angustifolius & SEM \\
\hline No. of cultivars & $n=6$ & $\mathrm{n}=3$ & $\mathrm{n}=2$ & \\
\hline 1000 seeds weight, $g$ & $131^{b}$ & $290^{\mathrm{a}}$ & $144^{\mathrm{b}}$ & 6.65 \\
\hline Dry matter & 898 & 912 & 910 & 2.27 \\
\hline Crude protein & $435^{\prime \prime}$ & $344^{b}$ & $331^{b}$ & 5.95 \\
\hline Ether extract & $53^{\mathrm{b}}$ & $105^{a}$ & $61^{b}$ & 1. \\
\hline Ash & $54^{\mathrm{a}}$ & $42^{\mathrm{b}}$ & $43^{b}$ & 0.85 \\
\hline \multicolumn{5}{|l|}{ Fibre fractions: } \\
\hline NSP & $321^{\mathrm{b}}$ & $398^{a}$ & $404^{\mathrm{a}}$ & 6.90 \\
\hline NDF & 254 & 235 & 261 & 3.44 \\
\hline ADF & 212 & 194 & 217 & 3.49 \\
\hline $\mathrm{CF}$ & 164 & 141 & 158 & 2.69 \\
\hline ADL & 21 & 27 & 21 & 1.08 \\
\hline hemicellulose & 45 & 42 & 44 & 2.80 \\
\hline cellulose & 188 & 167 & 192 & 3.31 \\
\hline
\end{tabular}

Oligosaccharides:

$\begin{array}{lrrrl}\text { sucrose } & 14.6^{\mathrm{b}} & 24.3^{\mathrm{a}} & 16.6^{\mathrm{ab}} & 1.0 \\ \text { galactopinitol } & 1.2^{\mathrm{b}} & 1.1^{\mathrm{b}} & 1.6^{\mathrm{a}} & 0.0 \\ \text { galactoinositol } & 1.6 & 1.8 & 1.5 & 0.1 \\ \text { raffinose } & 10.9 & 9.2 & 9.2 & 0.3 \\ \text { digalactopinitol } & 1.7^{\mathrm{b}} & 2.5^{\mathrm{a}} & 3.3^{\mathrm{a}} & 0.2 \\ \text { digalactoinositol } & 2.6^{\mathrm{b}} & 2.3^{\mathrm{b}} & 3.6^{\mathrm{a}} & 0.1 \\ \text { stachyose } & 59.5^{\mathrm{a}} & 63.7^{\mathrm{a}} & 32.7^{\mathrm{b}} & 2.0 \\ \text { verbascose } & 27.6^{\mathrm{a}} & 4.2^{\mathrm{b}} & 8.0^{\mathrm{b}} & 1.1 \\ \text { total } x \text {-galactosides } & 105.0^{\mathrm{a}} & 84.9^{\mathrm{b}} & 59.8^{\mathrm{c}} & 2.6 \\ \text { total oligosaccharides } & 119.6^{\mathrm{a}} & 109.2^{\mathrm{a}} & 76.4^{\mathrm{b}} & 2.8\end{array}$

NSP:

$\begin{array}{lcccc}\text { rhamnose } & 2^{\mathrm{c}} & 5^{\mathrm{a}} & 3^{\mathrm{b}} & 0.2 \\ \text { fucose } & 1 & 1 & 1 & 0.0 \\ \text { arabinose } & 40 & 43 & 43 & 4.1 \\ \text { xylose } & 37^{\mathrm{b}} & 45^{\mathrm{a}} & 32^{\mathrm{b}} & 1.0 \\ \text { mannose } & 7 & 9 & 8 & 0.3 \\ \text { galactose } & 62^{\mathrm{c}} & 126^{\mathrm{b}} & 150^{\mathrm{a}} & 2.6 \\ \text { glucose } & 138 & 125 & 123 & 3.5 \\ \text { uronic acids } & 35^{\mathrm{b}} & 44^{\mathrm{a}} & 44^{\mathrm{a}} & 0.7 \\ \text { total NSP } & 321^{\mathrm{b}} & 397^{\mathrm{a}} & 404^{\mathrm{a}} & 6.9\end{array}$

$a, b, c-P \leqslant 0.05$ 
chain of rhamnose and galactouronic acid linked by $\beta-(1-4)$ and $\alpha-(1-2)$ bonds, respectively (Annison, 1995).

Non-starch polysaccharides in animal feed are a complex group of components differing in chemical composition, physical properties and physiological activity. They can be divided into insoluble and soluble fractions, which can differ in nutritional effects. The insoluble NSP enclose nutrients forming a barrier to endogenous enzymes, while the soluble part can depress the digestibility of nutrients by changing conditions in the gut (i.e. viscosity). In the case of lupin seeds, the level of insoluble polysaccharides varied from 230 to 260 $\mathrm{g} / \mathrm{kg}$ DM. The soluble fraction of NSP calculated as the difference between NSP and NDF amounted, on average, $1070 \mathrm{~g}$ in L. luteus and $150 \mathrm{~g} / \mathrm{kg} \mathrm{DM}$ in L. albus and $L$. angustifolius. Only a small proportion of lupin NSP $(11-14 \%)$ is broken down in the pig's small intestine (Gdala et al., 1996). Most of the cell wall material undergoes fermentation in the large intestine.

Lupin seeds contain a high level of sucrose $\alpha$-galactosides and minor quantities of inositols and corresponding $\alpha$-galactosides (Obendorf and Horbowicz, 1994). These oligosaccharides are not hydrolyzed by digestive enzymes of pigs, but they are fermented by microflora in the digestive tract. In our previous studies (Gdala et al., 1996), it was shown that about $80 \%$ of the $\alpha$-galactosides were already broken down in the small intestine of young pigs fed a semisynthetic diet with lupin seed meal. The most important products of this process are volatile fatty acids (VFA), which appear to be an important energy source for pigs. It has been calculated that $50 \%$ of the VFA production arising from ingestion of lupin meals was from non-starch polysaccharides, and $50 \%$ from $\alpha$-galactosides (Champ et al., 1991). However, the amount of energy available from carbohydrate fermentation is expected to be lower than that from carbohydrates absorbed as monosaccharides. The differences result from additional losses as methane, fermentation heat and from slightly less efficient VFA utilization in the intermediary metabolism of animals (Müller and Kirchgessner, 1986).

\section{CONCLUSIONS}

In the present study, NSP and $\alpha$-galactosides constituted up to $48 \%$ of lupin seed dry matter. To improve utilization of these compounds as an energy source by pigs, feed enzymes should be added to lupin diets. It is important, however, that these enzymes release monosaccharides (glucose, galactose), which are effectively absorbed in the small intestine of pigs. 


\section{REFERENCES}

AOAC. 1990. Officials Methods of Analysis of the Association of Official Analytical Chemist. 15th Edition, Washington, DC

Annison G., 1995. Feed enzymes - the science, future developments and practical aspects in feed formulation. Procceedings of 10th European Symposium on Poultry Nutrition, Antalya (Turkey), pp.193-201

Bailey R.W., Mills S., Hove E. L., 1974. Composition of sweet and bitter lupin seed hulls with observations on the apparent digestibility of sweet lupin seed hulls by young rats. J. Sci. Food Agric. 25, 955-961

Brillouct J.M., Riochet D., 1983. Cell wall polysaccharides and lignin in cotyledons and huils of seeds from various lupin (Lupinus L.) species. J. Sci. Food Agric. 34, 861-868

Carré B., Brillouet J.M., Thibault J.F., 1985. Characterization of polysaccharides from white lupin (Lupinus alhus L.) cotyledons. J. Agric. Food Chem. 33, 285-292

Cerning-Beroard J., Filiatre A.. 1976. A comparison of the carbohydrate composition of lcgume secds: horscbeans, peas and lupines. Cereal Chem. 53, 968-978

Cerning-Béroard J., Filiatre-Verel A., 1980. Characterizalion and distribution of soluble and insoluble carbohydrates in lupin seeds. Z. Lebensm. Unters.-Forsch. 171, 281-285

Champ M., Berot B., Kozlowski F., Lecannu G., Delort-Laval J., 1991. Volatile fatty acid production from lupin meal in the caecum of the rat: the role of cell wall polysaccharides and $\alpha$-galactosides. Anim. Feed Sci. Technol. 32, 177-183

Englyst II.N., Cummings J.H., 1984. Simplified method for the measurement of total non-starch polysaccharides by gas-liquid chromatography of constituent sugars as alditol acetates. $A$ nalyst $109,937-942$

Gdala J., Buraczewska L., Jansman A.M.J.. Wasilcwko J., van Lecuwen P. 1994. Ileal digestibility of amino acids and carbohydrates in lupins for young pigs. In: W. B. Souffrant, H. Hagemeister (Editors). Procceedings of Vlth International Symposium on Digestive Physiology in Pigs, Bad Doberan, pp. 93-96

Gdala J., Jansman A.J.M., Buračewska L., Huisman J., van Leeuwen P., 1996. The influence of $\alpha$-galactosidase supplementation on the ileal digestibility of lupin seed carbohydrates and protein in young pigs. Anim. Fecd Sci. Technol. (in press)

Green A.G., Orad R.N., 1983. Variability for protein and oil quality in Lupinus albus. Anim. Feed Sci. Technol. 9, 271-281

Green A.G., Orad R.N., Read B.J., 1977. Genetic variation for seed yield, protein content, oil content, and seed weight in Lupinus albus. Aust. J. Agric. Res. 28, 785-793

Hill G.D., 1977. The composition and nutritive value of lupin seeds. Nutr. Abstr. Rev., Ser. B 47, $511-529$

Horbowicz M., Obendorf R.L., 1994. Seed desiccation tolerance and storability: Dependence on flatulence-producing oligosaccharides and cyclitols - review and survey. Seed Sci. Res. 4, $385-405$

Hove E. L., 1974. Composition and protein quality of sweet lupin seed. J. Sci. Food Agric. 25, $851-859$

Macrae R., Zand-Moghaddam A., 1978. The determination of the component oligosaccharides of lupin seeds by high pressure liquid chromatography. J. Sci. Food Agric. 29, 1083-1086

Müller H. L., Kirchgessner M., 1986. Some aspects of energy utilization in pigs. Pig News Inform. 7, 419-424

Múzquiz M., Burbano C., Rey C., Cassinello M., 1989. A chemical study of Lupinus hispanicus seed - nutritional components. J. Sci. Food Agric. 47, 197-204 
Trugo L.C., Almeida D.C.F., Gross R. 1988. Oligosaccharide contents in the seeds of cultivated lupins. J. Sci. Food Agric. 45, 21-24

Saini H. S., 1988. Extractability and evaluation of $x$-galactosides of sucrose in leguminous seeds. Food Chem. 28, 148-157

Sosulski F.W., Elkowicz L., Reichert R.D., 1982. Oligosaccharides in eleven legumes and their air-classified protein and starch fractions. J. Food Sci. 47, 489-502

Statgraphics Plus vr 7.0., 1993. Statistical Graphics System by Graphics Corporation

Van Soest P.J., 1973. Collaborative study of acid detergent fibre and lignin. J. Assoc. Off. Anal. Chem. Int. 56, 781-782

Van Soest P.J., Wine R.H., 1967. Use of detergents in the analysis of fibrous feeds. IV. Determination of plant cell constituents. J. Assoc. Off. Anal. Chem. Int. 50, 50-55

Withers N.J., King S., Hove E.L., 1975. Seed weight, proportion of seed coat, and nitrogen content of several species of sweet lupin: a note. N.Z.J. Exp. Agric. 3, 331-332

\section{STRESZCZENIE}

Skład chemiczny i zawartość węglowodanów w nasionach różnych gatunków fubinu

Zbadano zawartość i skład chemiczny wçglowodanów nasion sześciu odmian łubinu żółtego (Lupinus hteus L.), trzech odmian łubinu bialego (Lupinus albus L.) oraz dwóch odmian łubinu wąskolistnego (Lupinus angustifolius L.).

Badane nasiona różniły się istotnie ilością $x$-galaktozydów, których średnia zawartość $\mathbf{w} 1 \mathrm{~kg}$ suchej masy nasion lubinów żółtych wynosiła $105 \mathrm{~g}$ : łubinów białych $85 \mathrm{~g}$, a łubinów wąskolistnych $60 \mathrm{~g}$. Wśród $x$-galaktozydów dominowała stachioza. Nasiona łubinów żółtych i białych zawierały jej istotnie więcej (po ok. $60 \mathrm{~g}$ ) niż nasiona łubinów wąskolistnych (ok. $33 \mathrm{~g}$ ). Stwierdzono, że nasiona łubinów żóltych zawierały istotnie mniej $(321 \mathrm{~g})$ polisacharydów nieskrobiowych niż nasiona łubinów białych i wąskolistnych (ok. $400 \mathrm{~g}$ ). 